protein wheat and barley and in the possibilities of manipulating amino acid composition have encouraged breeders to proceed more positively with biochemical problems. In many ways this resurgence has been due to the wide publicity given to the potential of the opaque-2 gene in maize, and the high-lysine story has stimulated expectancies which I consider are rather rash in some cases.

These developments have provided, we hope, a new dimension to crop breeding, and have brought together biochemists, nutritionists, geneticists and plant breeders in intimate association. New genes or genotypic associations are being feverishly sought after: world collections are being ransacked, and recourse to the exploitation of the newly available cytogenetic and breeding techniques has already started. We shall hear more of these matters in the papers to follow.

\title{
Nutritional considerations in attempts to change the chemical composition of crops
}

\section{By K. J. Carpenter, Department of Agricultural Science and Applied Biology, University of Cambridge}

Improving the composition of crops by breeding has obvious advantages over many other ideas for raising nutritional standards in the world. Because of the long-term nature of such projects it is especially important that objectives should be thoroughly discussed before the criteria and priorities of selection are decided on.

History shows that effort can be wasted as a result of wrong assumptions about the nutritional aspects of a problem. For example, in the I930s it was recognized that pellagra, a serious disease in countries where the poor lived on maize as their staple food, was a deficiency disease responding to the vitamin nicotinic acid. It then seemed obvious that breeders should try to develop strains of maize having a higher content of nicotinic acid. And yet the idea was unsound. It now seems that the nicotinic acid is present in all grains in a nutritionally unavailable form (Chaudhuri \& Kodicek, I960). Other grains are better than maize in preventing pellagra because they contain more of the amino acid tryptophan. In the body, tryptophan (in excess of that required for protein synthesis) can be metabolized to nicotinic acid (Krehl, 1949). As would be expected, opaque-2 maize, with its higher tryptophan content, does prevent nicotinic acid deficiency in experimental animals (Bressani, Elias \& Gomez-Brenes, 1969).

This example illustrates the responsibility of nutritionists for checking as far as possible that the criteria they are suggesting for improving crops are effective ones. There seems a natural tendency for the nutrients which are newly discovered or the object of recent research to receive an undue amount of attention. Plant breeders must make definite 'yes or no' decisions about their priorities. If the nutritionists will not recommend nutritional priorities the selection will have 
to be done by non-specialists from their general impression of the current state of nutritional opinion. Table $\mathbf{I}$ represents an attempt to summarize such impressions at three periods of time.

Table I. An impression of opinions about desirable changes in human diet at different periods

\begin{tabular}{clll} 
To be increased: & \multicolumn{1}{c}{ 1930-50 } & \multicolumn{1}{c}{ 1950-65 } & \multicolumn{1}{c}{ Future } \\
Highest priority & Vitamins & Lysine & ? Starch \\
Second priority & Animal fat & $\begin{array}{l}\text { Protein } \\
\text { Vegetable fat }\end{array}$ & ? Mcthionine \\
& ? Trace minerals \\
No problems: & $\begin{array}{l}\text { Proteins } \\
\text { Minerals }\end{array}$ & $\begin{array}{l}\text { Vitamins } \\
\text { Minerals }\end{array}$ & ? \\
Excessive already: & Starch & Animal fat & ? Sucrose
\end{tabular}

\section{Sophisticated diets for animals}

Crops may be used either directly as human food or indirectly as fodder for productive animals. I will start by considering diets for intensively housed pigs and poultry in this country. We have a free market economy with complete flexibility of formulation, provided that nutrient requirements are met, with none of the problems of human dietetics as regards what changes are socially acceptable. Normally there is no expectation of making better diets, since they are thought to be fully balanced already; the whole operation of the compounding industry is to make equally good diets more economically and their success can be checked by actual performance.

It is difficult to split up the cost of providing the different nutrients in such mixtures when the ingredients are themselves complex matcrials, but it may be roughly estimated that $60 \%$ of the cost is for the provision of energy, $30 \%$ for protein and $5 \%$ for vitamins and minerals, with a final $5 \%$ for compounding the ingredients together. If a single crop could be produced that was completely balanced in itself, there would be substantial advantages because mixing costs would be eliminated. Otherwise, there is little economic advantage for the sophisticated market in selecting crops for higher concentration of vitamins or minerals that can be added very cheaply from other sources during ordinary mixing. Major economies in the cost of balanced rations can only come from cheapening the supply of energy or protein, or both.

Presumably there will continue to be the greatest interest in the improvement of those crops that are already good yielders of energy and protein. The major leastcost energy sources for dry, concentrated diets in this country are the cereal grains. Although the cereals contribute very important amounts of protein, even a $40 \%$ increase above present levels would be insufficient to balance diets for poultry and young pigs. There is therefore an interest in improved sources of home-grown supplementary protein and the legumes form the second main subject of the present symposium. 
Energy 'values' for intensive diets. The energy values of materials used for pig and poultry diets are commonly expressed in units of 'metabolizable energy' (ME), i.e. the gross energy of the food (measured as heat of combustion in a bomb calorimeter) less the gross energy of the fraction not combustible by the animals themselves (measured by bomb calorimetry of faeces and urine). There is reasonable evidence that the same quantity of ME from different cereals is of the same net energy value for the needs of these stock (cf. Carpenter, 1962).

The dry matter of one grain can have a slightly higher gross energy than that of another if it has a lower mineral content or a higher oil content or both. But there is little scope for lowering the former, and higher oil levels could be disadvantageous in other ways. The second and more important variable affecting ME is the degree of digestibility of the organic matter of the grain; this can vary greatly amongst the individual carbohydrates that are found in grains. The overall effect is illustrated in the following representative values (Hill, Anderson, Renner \& Carew, I960; Potter \& Matterson, 1960):

$\begin{array}{lccc}\text { Gross energy } & \begin{array}{c}\text { Metabolizable } \\ \text { energy (chicks) } \\ \text { (kcal/g) }\end{array} & \begin{array}{c}\text { ME as } \% \\ \text { of gross energy }\end{array} \\ \text { Maize } & 4.06 & 3.50 & 86 \\ \text { Sorghum } & 4.1 \mathrm{I} & 3 \cdot 3 \mathrm{I} & 8 \mathrm{I} \\ \text { Whcat } & 4.04 & 3 \cdot 10 & 77 \\ \text { Barley } & 4.02 & 2.64 & 66\end{array}$

Protein quantity and quality. When a figure is stated for the 'protein content' of a crop, it is usually the 'nitrogen content $\times 6 \cdot 25$ '. The digestibility is normally high $(90-95 \%)$ for concentrate foods and it is the variation in amino acid composition that is important. Since at least nine of the twenty or so amino acids that go to make up proteins have to be provided in the diet, there is not one requirement for protein but at least nine separate requirements for individual amino acids.

In practice, some of the essential amino acids are always present in the proteins of a mixed diet in lower proportions than they are in the mixed tissue proteins of the animal eating them. When the lysine concentration of the dietary proteins is half that in the body proteins it follows, since lysine cannot be synthesized in the body, that from $100 \mathrm{~g}$ of such dietary protein one could only expect a synthesis of $50 \mathrm{~g}$ body protein, at maximum. If this rate of conversion were confirmed in animal experiments, the protein would be said to have shown a 'net protein utilization' (NPU) of $50 \%$.

If a complete chemical analysis for the amino acid composition of the dietary protein has been carried out, the level of each amino acid can be compared with that in a perfect or 'reference' protein for the animal concerned. If it is found that lysine is present in lowest proportion to requirement (i.e. $50 \%$ ), then it is said that the chemical score of the dietary protein as a whole is $50 \%$. Comparison of published 'chemical scores' and NPU values indicates that most of the variability in nutritional value of the proteins in unprocessed foods can be explained by the extent of their deficiency in the first limiting amino acid (Block \& Mitchell, 1946-7; McLaughlan, Rogers, Chapman \& Campbell, 1959). 
Table 2. Representative values for the crude and net protein content of important foods (based on tables of Kuppuswamy, Srinivasan $\&$ Subrahmanyan, 1958)

\begin{tabular}{|c|c|c|c|}
\hline Food & $\begin{array}{l}\text { Crude protein } \\
\text { content }(\%)\end{array}$ & $\begin{array}{l}\text { Net protein utilization (\%) } \\
\text { (and first limiting amino acid) }\end{array}$ & $\begin{array}{l}\text { Net protein } \\
\text { content }(\%)\end{array}$ \\
\hline $\begin{array}{l}\text { Wheat } \\
\text { Barley } \\
\text { Sorghum } \\
\text { Maize } \\
\text { (opaque-2 maize) }\end{array}$ & $\begin{array}{l}\text { I2 } \\
10 \\
9 \\
8 \cdot 5 \\
\text { II } 5\end{array}$ & $\left.\begin{array}{l}60 \\
60 \\
50 \\
50 \\
75\end{array}\right\}$ (? isoleucine) & $\begin{array}{l}7 \cdot 2 \\
6 \cdot 0 \\
4 \cdot 5 \\
4 \cdot 3 \\
? 8 \cdot 6\end{array}$ \\
\hline $\begin{array}{l}\text { Phaseolus beans } \\
\text { Peas } \\
\text { Soya beans } \\
\text { Groundnuts }\end{array}$ & $\begin{array}{l}25 \\
23 \\
35 \\
28\end{array}$ & $\left.\begin{array}{c}45^{*} \\
45 \\
65^{*}\end{array}\right\}$ (methionine) & $\begin{array}{l}\text { I1 } \\
\text { I0 } \\
23 \\
15\end{array}$ \\
\hline $\begin{array}{l}\text { Cow's milk } \\
\text { Beef muscle } \\
\text { Whole egg }\end{array}$ & $\begin{array}{l}25 \dagger \\
75 \dagger \\
75 \dagger\end{array}$ & $\begin{array}{l}80 \text { (methionine) } \\
75 \text { (methionine) } \\
95 \text { - }\end{array}$ & $\begin{array}{l}20 \dagger \\
56 \dagger \\
71+\end{array}$ \\
\hline
\end{tabular}

It has been a common convention to multiply the actual protein content of a food by its percentage NPU (or an estimate of NPU calculated from chemical score) to give a figure for 'net protein value' or 'complete protein' content of a food (Howard, Monson, Bauer \& Block, 1958). This has been done for a range of foods in Table 2.

The 'protein' (i.e. the composite mixture of proteins present) in each of the cereal grains is limiting in lysine. This seems to point strongly to the value of

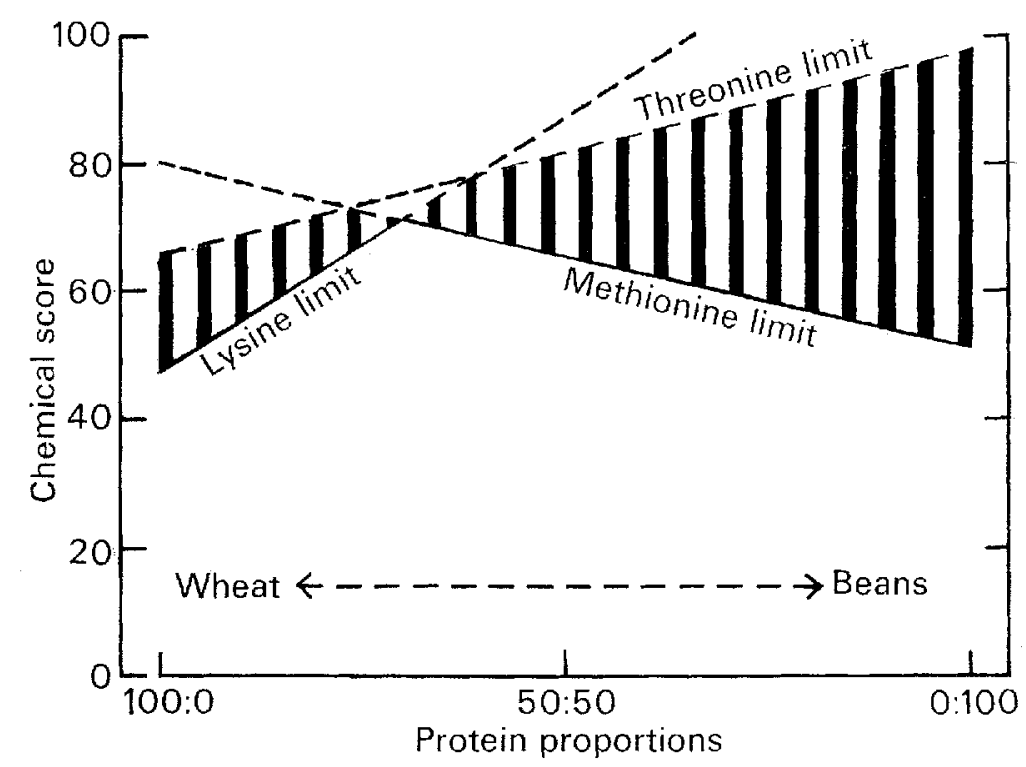

Fig. I. The calculated chemical score of whole wheat and Phaseolus bean proteins in differing proportions. The shaded area on the left represents the improvement possible from added lysine and that on the right the improvement from added methionine. (The reference standard is taken from Bender (I965) with additional analyses from Kakade \& Evans (1963)). 
supplementing cereals with lysine, either directly as the synthetic supplement or, in the long term, by breeding varieties of higher lysine content. However, most of the protein sources such as legumes, that are used to supplement the cereal proteins in balanced diets, have a higher lysine content and are limited by their relative deficiency in the sulphur-containing amino acids, i.e. methionine and cystine.

Which amino acid one would expect to be limiting in a cereal-legume mixture depends on the proportions, as is illustrated in Fig. 1. The reference standard was based on rat experiments. Slightly different standards are used for other species but the figure illustrates some general points: (a) raising the level of any amino acid but the one limiting the actual mixture is of no value; (b) increasing the level of the first limiting amino acid can only raise the value of the mixture to the level limited by the next amino acid; and (c) mixing two proteins may give mutual supplementation without the addition of amino acids. Patwardhan (196I) has confirmed the supplementation between cereals and legumes in feeding trials with rats.

Economic value of different changes. We have now considered several nutrientscalories, protein, lysine and methionine. The problem is to know their relative economic importance for breeding projects. Prices fluctuate with time and place but it is still instructive to consider even a single situation. We have chosen barley and made calculations, following commercial practice, with feeding-stuffs at prices expected to prevail in the autumn of 1969 in southern England, including DLmethionine at $£ 450 /$ ton and L-lysine hydrochloride at $£_{7} 65 /$ ton (D. B. P. Cressall $\&$ K. J. Carpenter, unpublished results).

An analogue computer was instructed to choose least-cost mixtures that met the nutritional criteria specified for each particular class of livestock. Beginning with young broilers, the price of barley was then varied until the price was found that just corresponded to an inclusion rate of $20 \%$-in this instance $\oint_{1} 8 \cdot 1 /$ ton. Standard barley (i.e. with crude protein $10 \%$, lysine $0.35 \%$, methionine $0.15 \%$, cystine $0.23 \%$, ME $2.64 \mathrm{kcal} / \mathrm{g}$, etc.) was then replaced by a hypothetical barley of $10 \%$ higher ME value; the price at which it was included at $20 \%$ in the new least-cost formula was $£_{2} \mathrm{I} \cdot 7 /$ ton, i.e. $20 \%$ of the corresponding price for the standard barley. These calculations were continued with the results set out in Table 3 .

Table 3. Effect of changes in composition on the calculated 'opportunity prices' of barley and field beans in least-cost diets of different types

Type of diet

Level of inclusion of test material (\%) Opportunity price of standard crop ( $f /$ ton) Relative opportunity prices for modified crop:

(1) ME up 10\%

(2) Lysine up 20\%

(3) Methionine + cystine up 20\%

(4) Protein up $20 \%$ (amino acids in proportion)

\begin{tabular}{|c|c|c|c|c|}
\hline \multicolumn{4}{|c|}{ Barley } & Field \\
\hline $\begin{array}{l}\text { Broiler } \\
\text { starter }\end{array}$ & $\begin{array}{c}\text { Battery } \\
\text { layer }\end{array}$ & $\begin{array}{l}\text { Heavy } \\
\text { hog }\end{array}$ & $\begin{array}{l}\text { Pig } \\
\text { rearer }\end{array}$ & $\begin{array}{l}\text { Pig } \\
\text { rearer }\end{array}$ \\
\hline $\begin{array}{l}20 \\
18.1\end{array}$ & $\begin{array}{l}20 \\
1722\end{array}$ & $\begin{array}{c}50 \\
23 \cdot 2\end{array}$ & $\begin{array}{c}50 \\
22 \cdot 0\end{array}$ & $\begin{array}{c}5 \\
36 \cdot 1\end{array}$ \\
\hline I 20 & 120 & 108 & I06 & 105 \\
\hline 104 & 100 & 103 & $10_{4}$ & 105 \\
\hline 100 & IOI & 100 & 100 & 100 \\
\hline I09 & I IO & 104 & 104 & 110 \\
\hline
\end{tabular}


For the pig diets a similar procedure was followed, with the standard level of inclusion set at $50 \%$. A second set of figures for a pig rearer diet was based on the situation of a pig feeder growing his own barley and using it as the sole cereal in his rations-it was then calculated how much more he could value his barley per ton if he grew a modified strain and his feeding was still to cost the same. The results were almost exactly the same as those obtained by the first method.

The most striking figures in Table 3 are of a $10 \%$ increase in ME giving an apparent $20 \%$ increase in economic value of barley when used in broiler and layer rations. This arises from the common specification for such poultry diets that they must contain not less than 2.65 and $2.80 \mathrm{kcal} / \mathrm{g}$ respectively. Since the formulas have to include mineral supplements with no energy value, the remaining materials must have a higher average ME. Standard barley is penalized because it can only be included if 'paired' with another material of higher ME, and the concentrated sources of energy, such as maize and fat, are usually expensive. In pig rations less concentrated mixtures are acceptable or even preferred : standard barley is more highly valued there and the premium for a 10\% energy increase is only $6-8 \%$ (Table 3 ).

The economic effects of changes in the protein of barley are what might be expected, with lysine being a cost-limiting factor in three of the diets and the sulphurcontaining amino acids taking over this position in the layers ration. This is in general agreement with American experience with modified maize, though Cromwell, Rogler, Featherston \& Cline ( 1968 ) found that even with growing chicks increasing the lysine content gave no benefit while increasing methionine level did have an effect. The values of barleys for pig rations are generally similar to the results of earlier calculations (Carpenter \& Taylor, 1968). It is clear that both increases in total protein content (of the same amino acid composition) and increases in the proportion of lysine in the grain increase its value. Hadley (1966) in a study of the economic value of opaque- 2 maize in pig feeding has estimated that it would be worth $7^{-22} \%$ more than ordinary maize, according to the relative prices of maize and soya-bean meal.

Such information allows comparison of the value of changes in composition with the extra returns that could come from varieties giving higher yields of the same composition. The further problem of how a market can be organized so that growers receive appropriate recompense for crops of improved composition will be considered later (Mossberg, 1970).

Experience from feeding trials. There is significant variability in the ME of different samples of barley for chicks (Lcong, Jensen \& McGinnis, 1962). This has not yet been correlated for certain with simple analytical characteristics, although some suggestions have been made (Burnett, 1966). Each sample, therefore, requires a small feeding test and approximately $\mathrm{I} \mathrm{kg}$ is needed. Some samples of low ME may be improved by preliminary soaking or enzyme treatment, or both, that appears to modify some of the structural carbohydrates which are present in variable amounts and are responsible for reducing general digestibility (Leong et al. 1962; Potter, Stutz \& Matterson, 1965). This aspect seems worth systematic investigation in connexion with breeding programmes. 
Other speakers will be describing the progress being made in changing the protein and amino acid contents of grains. With opaque-2 maize there is no doubt that the large changes in chemical composition have been accompanied by corresponding changes in nutritional value (Cromwell, Pickett \& Beeson, i967; Cromwell et al. I968), i.e. the extra nutrients found on analysis are biologically available. With the smaller changes that have been found so far in other grains it is, of course, more difficult to confirm the effects by actual feeding trials. Jones, Cadenhead \& Livingstone (1968), comparing two samples of barley in a trial with bacon pigs, obtained a just significant advantage with the sample containing more lysine. On the other hand, Brune, Thier \& Borchert (1968) could find no correlation between the feeding value of a series of barley samples (differing in fertilizer treatment as well as variety) and their amino acid composition as determined by chemical analysis. It may be that differences in digestibility, of the kind already considered in relation to energy values, are operating to produce such results. Alternatively the inherent variability between animals may be obscuring genuine, but small, differences between the test materials.

\section{Human diets}

Vitamins. Man requires the same range of nutrients as do the single-stomached domestic animals, with vitamin $\mathrm{C}$ in addition. There are still some areas of vitamin deficiency-particularly deficiency of thiamine, amongst those with refined rice as their staple, and of vitamin A. Bulk supplies of synthetic vitamin A are now so cheap that their cost is not the limiting factor, but it seems an insoluble problem to fortify a child's diet if the mother lives in a remote village, buys no processed food and is not in contact with any Government service. Under such conditions the introduction into the area of a new strain of the traditional staple crop with a higher vitamin A content could make all the difference. Presumably this could only be achieved with crops such as maize and sorghum where carotenoids are already present in some strains.

It has been past experience that nutritionally improved crops will only be adopted if they have all the accustomed culinary qualities (e.g. texture and flavour) as well as giving good yields. Even the colour of extra carotenoids may make an 'improved' variety unacceptable. With the $B$ vitamins, and particularly thiamine, it is important to consider only the concentration in the cereal as eaten. Extra vitamin present in the portion of the grain that is lost during preparation of a food obviously has no significance.

Calories and protein. For the poor of many developing countries there is a scarcity of calories, so that they can maintain their energy balance only by curtailing their physical activity, even when they spend so much of their income on staple foods that little is left for other things.

Human growth and reproduction rates are, in proportion to size, very much less than those in animals. As one would expect, therefore, man's requirements for protein in relation to calories are also considerably lower (Fig. 2). For example, in the studies of Widdowson \& McCance (1954) schoolchildren grew normally on 
diets in which only $12 \%$ of the calories came from protein $(87 \%$ of this being vegetable protein, mostly from white bread) and which contained no supplementary vitamins or amino acids. Nevertheless, there is a fairly widespread protein deficiency disease (kwashiorkor) amongst newly weaned, preschool children in some tropical countries.

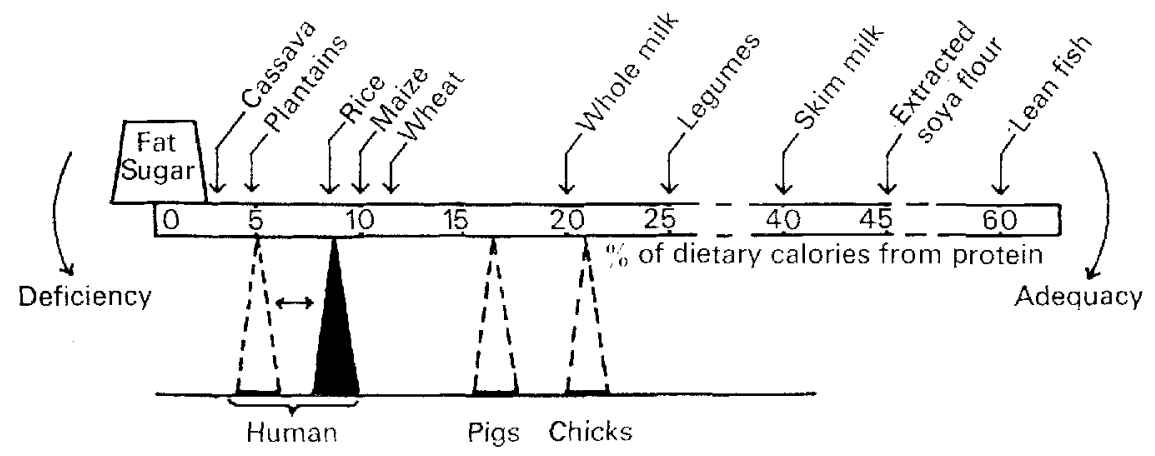

Fig. 2. A diagram representing a scale of $P(\%$ of dietary calories coming from protein) with the position of individual foods along the scale indicated (after Autret \& Jacquot, 196I). The maximum amount of protein required by growing children receiving a mixed diet is represented as a fulcrum on which the scale is balanced. The range of values for man, and approximate balance points for productive pigs and poultry, are also indicated. The values for man are based on FAO (1965) estimates with an allowance for the dietary protein having a score of 60.

Lysine or methionine. Whether or not lysine is in general the first limiting factor in human diets where protein nutrition is suboptimal is a matter of controversy. The subject has come to a head now that it is technically possible to produce synthetic lysine on a very large scale. Some are in favour of using it, for example, as an additive in all wheat shipments sent to India (Howe, Jansen \& Gilfillan, I965; Howe, Jansen \& Anson, I968); others are sceptical (Hegsted, I968; King, I968; Gounelle, 1969).

Although lysine is certainly the first limiting amino acid in cereals taken alone, it has been found that for all examples of average national diets, even from countries where cases of protein deficiency are seen amongst the children, the first limiting amino acid is methionine (Miller \& Donoso, I963). This was so both by calculation of the chemical composition of the mixed protein of the diet and by actual feeding trial of similar mixtures with rats. More recent calculations of the composition of national average diets, based on FAO information, confirms that lysine hardly ever appears to be the limiting amino acid with characteristic regional diets, and that it is usually the sulphur-containing amino acids (Autret, Périssé, Sizaret $\&$ Cresta, I968).

Those stressing the importance of lysine would probably argue that where the staple is a cereal we are concerned not with the average member of a community but with the small minority who become ill with protein deficiency because they receive diets of less-than-average quality. These presumably have their lysinedeficient staples supplemented with a greater proportion of 'empty' calories (i.e. fats, starches and sugar) and less of the protein-rich supplements, such as animal 
products and legumes, that are rich in lysine. Experimental results from India indicate that a children's orphanage diet, based on Kaffir corn (Sorghum vulgare), does give better growth when supplemented with lysine (Doraiswamy, Subramanya Raj Uns, Venkat Rao, Swaminathan \& Parpia, 1968). This controversy is, of course, perplexing for breeders trying to decide whether to select for lysine specifically or for greater protein in cereals.

In communities where the staples are not cereals but starchy materials such as cassava or plantains with an extremely low protein content there is, necessarily, an absolute reliance on the supplementary foods to supply an adequate balance of protein in the diet. The contribution of legumes in particular is to be discussed later in the symposium; many varieties contain inhibitors or toxins which put an upper limit on their use and the value of their protein is limited by its relative deficiency of methionine (cf. Aykroyd \& Doughty, I964).

It can be argued that the 'world protein gap' (United Nations, I968) does not exist and that sufficient protein is almost always available if only it is allocated efficiently between members of the family. Certainly the occurrence of cases of protein deficiency amongst weanlings is due largely to ill-informed feeding practices, particularly those adopted when the child is attacked with diarrhoea (Brock, I96r). The trend in recent years has been to revise downwards the estimates of the protein requirements of populations as a whole (FAO, 1965). Equally it has been emphasized that if supplementary protein is given to people deficient in overall calorie intake the protein will be metabolized for energy purposes which have priority (cf. Gounelle, r 969).

In our own affluent society, with the problem of overnutrition, we tend to think 'protein good, calories bad'. For the world as a whole we must think 'protein good, calories good'. While encouraging plant breeders who are working to raise the protein and essential amino acid content of staple foods we must equally encourage the development of higher-yielding varieties even if they have the same chemical composition-their contribution to better nutrition is at least as great. All over the world, whenever cereal staples have become more abundant and people have been able to afford to supplement their diet more liberally, they have done so with highprotein, high-vitamin materials. Moreover, any surpluses of staples can be fed to livestock and converted into foods, such as eggs and milk, ideal for vulnerable groups. At the same time a moderate surplus in good years provides a margin of safety for adverse years.

I am indebted to Colborn Vitafeeds Ltd for help with the use of an analogue computer and matrices for formulating least-cost diets.

\section{REFERENCES}

Autret, M. \& Jacquot, R. (rg6r). Fedn Proc. Fedn Am. Socs exp. Biol. 2o, Suppl. no. 7, p. 89. Autret, M., Périssé, J., Sizaret, F. \& Cresta, M. (1968). Nutrition News Letter 6, no. 4, p. I. Aykroyd, W. R. \& Doughty, J. (1964). F.A.O. Nutr. Stud. no. 19.

Bender, A. E. (1965). Proc. Nutr. Soc. 24, 190.

Block, R. J. \& Mitchell, H. H. (1946-7). Nutr. Abstr. Rev. r6, 249. 
Bressani, R., Elias, L. G. \& Gomez-Brenes, R. A. (1969). F. Nutr. 97, 173.

Brock, J. F. (196r). Fedn Proc. Fedn Am. Socs exp. Biol. zo, Suppl. no. 7, p. 6 r.

Brune, H., Thier, E. \& Borchert, E. (1968). Z. Tierphysiol. Tieremähr. Futtermittelk. $24,89$.

Burnett, G. S. (1 966). Br. Poult. Sci. 7, 55.

Carpenter, K. J. (1962). In Nutrition of Pigs and Poultry. Ch. 3. [J. T. Morgan and D. Lewis, editors.] London: Butterworth.

Carpenter, K. J. \& Taylor, J. H. (1968). Proc. Nutr. Soc. 27, IA.

Chaudhuri, D. K. \& Kodicek, E. (1960). Br. $\mathcal{F}$. Nutr. 14, 35.

Cromwell, G. L., Pickett, R. A. \& Beeson, W. M. (1967). F. Anim. Sci. 26, 1325.

Cromwell, G. L., Rogler, J. C., Featherston, W. R. \& Cline, T. R. (I968). Poult. Sci. 47, 840.

Doraiswamy, T. R., Subramanya Raj Uns, T. S., Venkat Rao, S., Swaminathan, M. \& Parpia, H. A. B. (1968). F. Nutr. Dietet. 5, 191.

FAO (1965). F.A.O. Nutr. Mtg Rep. Ser. no. 37.

Gounelle, H. (1969). Am. F, clin. Nutr. 22, 4.

Hadley, N. S. (rg66). Proc. High Lysine Corn Conf. (Purdue), p. i6r.

Hegsted, D. M. (1968). Am. F. clin. Nutr. 21, 688.

Hill, F. W., Anderson, D. L., Renner, R. \& Carew, L. B. (1960). Poult. Sci. 39, 573.

Howard, H. W., Monson, W. J., Bauer, C. D. \& Block, R. J. (1958). F. Nutr. 64, I5I.

Howe, E. E., Jansen, G. R. \& Anson, M. L. (1968). Am. F. clin. Nutr. 21, 523.

Howe, E. E., Jansen, G. R. \& Gilfillan, E. W. (1965). Am. F. clin. Nutr. I6, 315.

Jones, A. S., Cadenhead, A. \& Livingstone, R. M. (1968). F. Sci. Fd Agric. 19, 446.

Kakade, M. L. \& Evans, R. J. (1963). Q. Bull. Mich. St. Univ. agric. Exp Stn 46, 87.

King, K. W. (r968). Am. Y. clin. Nutr. 2x, 523.

Krehl, W. A. (1949). Vitams Horm. 7, III.

Kuppuswamy, S., Srinivasan, M. \& Subrahmanyan, V. (1958). Spec. Rep. Ser. Indian Coun. med. Res. no. 33 .

Leong, C. K., Jensen, L. S. \& McGinnis, J. (1962). Poult. Sci. 41, 36.

McLaughlan, J. M., Rogers, C. G., Chapman, D. G. \& Campbell, J. A. (1959). Can. F. Binchem. Physiol. 37, 1293.

Miller, D. S. \& Donoso, G. (1963). F. Sci. Fd Agric. 14, 345.

Mossberg, R. (1970). Proc. Nutr. Soc. 29, 39.

Patwardhan, V. N. (196r). Publs natn. Res. Coun., Wash. no. 843, p. 201.

Potter, L. M. \& Matterson, L. D. (1960). Poult. Sci. 39, $78 \mathrm{r}$.

Potter, L. M., Stutz, M. W. \& Matterson, L. D. (r965). Poult. Sci. 44, 565.

United Nations (1968). International Action to Avert the Impending Protein Crisis. New York: United Nations.

Widdowson, E. M. \& McCance, R. A. (1954). Spec. Rep. Ser, med. Res. Coun, Lond. no. 287.

\section{The physiology of the synthesis of amino acids and their movement into the seed proteins of plants}

\section{By B. F. Folkes, School of Biological Sciences, University of East Anglia, Norwich}

As far as is possible I have combined information derived from the work of two research groups in order to describe an idealized plant. Professor E. W. Yemm's group at Bristol, with which I was associated for over 20 years, carried out in the period I $945^{-60}$ a fairly extensive investigation of the amino acid metabolism of barley (Hordeum distichon Spratt Archer), while more recently Dr J. S. Pate and his colleagues at Belfast have provided us with a most comprehensive description of the synthesis of amino acids and carbohydrates in the field pea (Pisum arvense). Much of this work has been reviewed by Yemm \& Folkes (1958) and Pate (r 968). These two series of investigations are complementary, both because of the very different character of the plants involved and because of the use by the Bristol group of ${ }^{15} \mathrm{~N}$ as a tracer while the Belfast group used exclusively ${ }^{14} \mathrm{C}$. 